\title{
PEMANFAATAN AIR KELAPA MENJADI NATA DE COCO BAGI PEREMPUAN DI SEKITAR PASAR PANORAMA KOTA BENGKULU
}

\section{UTILIZATION OF COCONUT WATER TO BE NATA DE COCO FOR WOMEN IN PASAR PANORAMA BENGKULU CITY}

\author{
Oleh: \\ Tuti Tutuarima ${ }^{1}$, Yessy Rosalina ${ }^{1}$, Arini Azka Muthia ${ }^{2}$ \\ ${ }^{1}$ Jurusan Teknologi Pertanian Universitas Bengkulu \\ ${ }^{2}$ Jurusan Ilmu Hukum Universitas Bengkulu \\ tutitutuarima@unib.ac.id
}

\begin{abstract}
Coconut water is a waste from the production of fresh coconut milk in the Panorama Market that has not been utilized. Coconut water can be used in making nata de coco. Processing of coconut water into nata de coco has a high economic value. The purpose of this activity was to provide knowledge and skill through empowering women around the Panorama Market to utilize coconut water in the nata de coco production, in order to improve their family income. Activities were carried out through stages: socialization, motivational counseling, practice of making nata de coco, processing of nata de coco into beverage products, training in product packaging and labeling, and evaluation. The number of participants who attended the event were 15 people consisting of mothers and young women around the Panorama Market. The participants had a good response to activities the delivered knowledge ad skill, and increased motivation of participants and intended to produce nata de coco as an alternative business.
\end{abstract}

Keywords : nata de coco, beverage product, family income.

\section{PENDAHULUAN}

Perubahan gaya hidup masyarakat yang ingin serba praktis mendorong munculnya usaha-usaha baru untuk memenuhi kebutuhan tersebut. Salah satunya adalah peningkatan jumlah pedagang santan segar di beberapa pasar tradisional, diantaranya adalah Pasar Panorama Kota Bengkulu. Usaha penjualan santan segar menggunakan kelapa sebagai bahan baku. Produksi santan kelapa ini menghasilkan berbagai limbah, salah satunya berupa air kelapa. Air kelapa memiliki komposisi kimia karbohidrat, protein, lemak, vitamin, dan mineral yang sangat baik bagi tubuh manusia. Komponen karbohidrat berupa sukrosa dan fruktosa dapat dimanfaatkan sebagai bahan baku pembuatan nata de coco. Pengolahan air kelapa menjadi nata de coco ini memiliki nilai ekonomi yang tinggi. Nata de coco adalah jenis komponen minuman yang merupakan senyawa selulosa (dietary fiber), yang dihasilkan dari air kelapa melalui proses fermentasi, yang melibatkan mikroba golongan bakteri Acetobacter xylinum (Pambayun. 2002). Proses pengolahan limbah air kelapa menjadi nata de coco sebenarnya mudah dan tidak membutuhkan waktu yang lama. Selanjutnya, nata de coco dapat diolah menjadi minuman segar yang bernilai ekonomis. Namun, hingga saat ini sebagian besar pelaku usaha santan membuang air kelapa tanpa 
dimanfaatkan lebih lanjut. Minimnya pengetahuan yang dimiliki pedagang ataupun masyarakat sekitar menjadi kendala dalam mengelola limbah air kelapa tersebut.

Keberadaan limbah air kelapa yang melimpah dan potensi yang dimilikinya, merupakan salah satu peluang sumber pendapatan ataupun sebagai tambahan penghasilan keluarga yang dapat dilakukan oleh masyarakat di sekitar Pasar Panorama terutama ibu-ibu dan remaja putri. Perempuan-perempuan di wilayah ini memiliki latar belakang pendidikan dan profesi yang berbeda-beda. Sebagian bekerja sebagai buruh di Pasar Panorama \& berdagang kecil-kecilan, sebagian hanya beraktivitas di rumah, dan sebagian kecil yang bekerja sebagai karyawan/pegawai. Peran serta perempuan memberikan kontribusi yang cukup besar untuk mendukung kesejahteraan keluarga. Perempuan memiliki potensi untuk mengembangkan diri melalui berbagai keterampilan. Peningkatan keterampilan bagi perempuan-perempuan ini selain bermanfaat untuk mengisi waktu luang, juga dapat menjadi usaha produktif sebagai alternatif sumber pendapatan keluarga.

Tujuan dari kegiatan ini adalah menggali dan memanfaatkan potensi yang dimiliki khalayak sasaran untuk kegiatan usaha ekonomi mandiri yang dapat menjadi alternatif sumber pendapatan, mengenalterapkan pengetahuan dan keterampilan kepada khalayak sasaran mengenai pengolahan air kelapa menjadi nata de coco, pengolahan nata de coco menjadi minuman siap saji, serta pengemasan produk untuk pemasaran.

\section{METODE PENGABDIAN}

Kegiatan pengabdian ini dilaksanakan sejak bulan Juni - Oktober 2018. Kegiatan ini diperuntukkan bagi perempuan-perempuan yang berdomisili di sekitar Pasar Panorama bekerjasama dengan PC Salimah Kecamatan Singaran Pati Kota Bengkulu. Khalayak sasaran ini ditentukan berdasarkan pertimbangan bahwa banyaknya jumlah perempuan di sekitar Pasar Panorama usia produktif yang sebagian besarnya hanya beraktivitas di rumah. Khalayak sasaran ini diperkirakan berjumlah sekitar 15 - 20 orang.

Rangkaian pengabdian ini terdiri dari beberapa kegiatan, antara lain : koordinasi dengan mitra, sosialisasi kegiatan kepada khalayak sasaran, penyuluhan dan pelatihan pengolahan air kelapa menjadi nata de coco, praktek pengolahan nata de coco menjadi produk siap saji, penyuluhan teknologi pengemasan dan labelling produk serta cara menghitung harga jual produk. Koordinasi dengan mitra dilakukan untuk menentukan waktu pelaksanaan kegiatan pengabdian yang sesuai dengan aktivitas khalayak sasaran. Pemberian sosialisasi kepada khalayak sasaran mengenai kegiatan yang akan dilaksanakan. Kegiatan penyuluhan dilakukan untuk memberikan pengetahuan dan keterampilan mengenai pemanfaatan air kelapa menjadi nata de coco dan pengolahan nata de coco menjadi berbagai produk, memberikan pengetahuan tentang cara pengemasan, pelabelan, dan penyimpanan produk yang baik serta juga memberikan pengetahuan tentang cara menghitung harga jual produk yang dihasilkan. Selanjutnya peserta juga dilibatkan secara langsung dalam kegiatan ini melalui praktek (learning by doing).

\section{HASIL DAN PEMBAHASAN}

\section{Koordinasi dengan Mitra (Salimah PC Singaran Pati)}

Koordinasi dengan mitra dilakukan dengan intensif baik melalui pertemuan langsung ataupun dengan media komunikasi (whatsapp). Kegiatan koordinasi ini merupakan kegiatan awal dengan mitra dalam hal ini adalah Pengurus Cabang Persaudaraan Muslimah (PC Salimah) Kecamatan Singaran Pati. Melalui koordinasi ini, tim pelaksana mendapatkan informasi mengenai aktivitas yang dikelola oleh PC Salimah 
Singaran Pati. Selama ini kegiatan pemberdayaan perempuan hanya dalam bentuk pengembangan keilmuan agama (majlis taklim dan baitul quran). Sementara pemberdayaan yang mengarah pada kreatifitas ekonomi produktif belum dilakukan. Mengingat jumlah perempuan dilingkungan tersebut yang sebagian besarnya adalah ibu rumah tangga tanpa pekerjaan sampingan, maka kegiatan yang mengarah pada ekonomi produktif sangat perlu untuk dilakukan.

Hasil koordinasi dengan pengurus PC Salimah Singaran Pati disepakati bahwa akan dilaksanakan kegiatan pelatihan pembuatan nata de coco. Hal ini mengingat bahwa banyaknya air kelapa yang belum dimanfaatkan secara optimal di lingkungan sekitar tempat tinggal mereka yaitu lingkungan Pasar Panorama. Pelaksanaan kegiatan ini direncanakan pada minggu ke-4 bulan Agustus 2018 dan sosialisasi dilakukan pada kegiatan rutin arisan RT.

\section{Sosialisasi Kegiatan Pelatihan Pembuatan Nata De Coco}

Sosialisasi kegiatan PPM Pembinaan ini dilaksanakan pada tanggal 21 Juli 2018 bertepatan dengan kegiatan rutin arisan RT. Sosialisasi ini bertujuan untuk mengajak ibuibu turut serta pada kegiatan ini. Peserta kegiatan ini ditargetkan berkisar antara 10-15 orang. Ibu-ibu tersebut sangat antusias terhadap rencana kegiatan ini, sehingga yang berminat untuk ikut kegiatan ini lebih dari 15 orang. Di akhir kegiatan sosialisasi ini disepakati bahwa pelaksanaan kegiatan akan dimulai pada minggu ke-4 bulan Agustus 2018 .
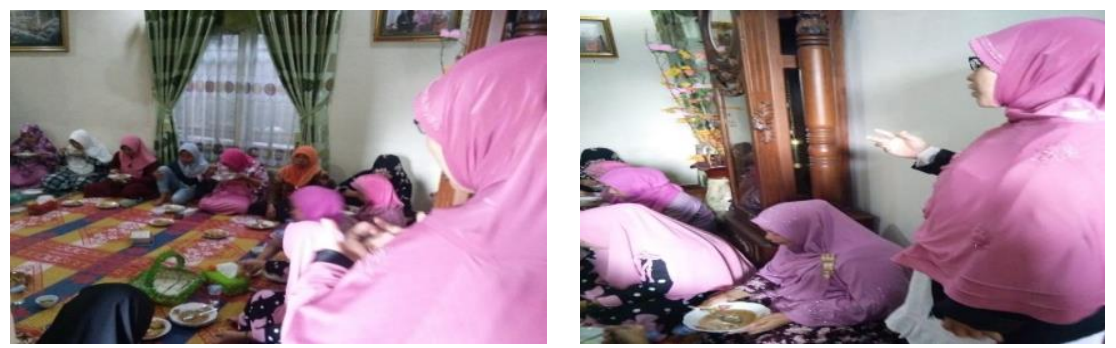

Gambar 1. Sosialisasi kegiatan

\section{Pelatihan Pembuatan Nata De Coco}

Pelatihan pengolahan air kelapa menjadi produk siap jual diharapkan dapat menjadi salah satu alternatif pilihan produk yang bisa mereka usahakan. Kegiatan ini dilaksanakan di Sekretariat PC Salimah Singaran Pati di Jalan Gandaria RT 21 RW 07 Kel. Panorama Kec. Singaran Pati Kota Bengkulu. Kegiatan ini dihadiri oleh 15 orang peserta.

Pelatihan pembuatan nata de coco diawali dengan pemberian materi mengenai pengenalan bahan dan proses pembuatan nata de coco. Pemberian materi ini bertujuan untuk memperkenalkan bahan-bahan yang akan digunakan pada pembuatan nata de coco. Pada sesi ini, para peserta juga bertanya mengenai penggunaan pupuk pada pembuatan nata de coco. Hal-hal penting yang harus dilakukan selama pembuatan nata de coco juga disampaikan pada kegiatan ini.

Kegiatan selanjutnya adalah praktek pembuatan nata de coco. Pada kegiatan ini peserta diajarkan teknik pembuatan nata de coco. Terutama teknik sterilisasi alat dan bahan yang digunakan, karena jika teknik ini tidak dikuasai maka kemungkinan besar mikroorganisme pembentuk nata de coco tidak akan tumbuh dengan baik. 

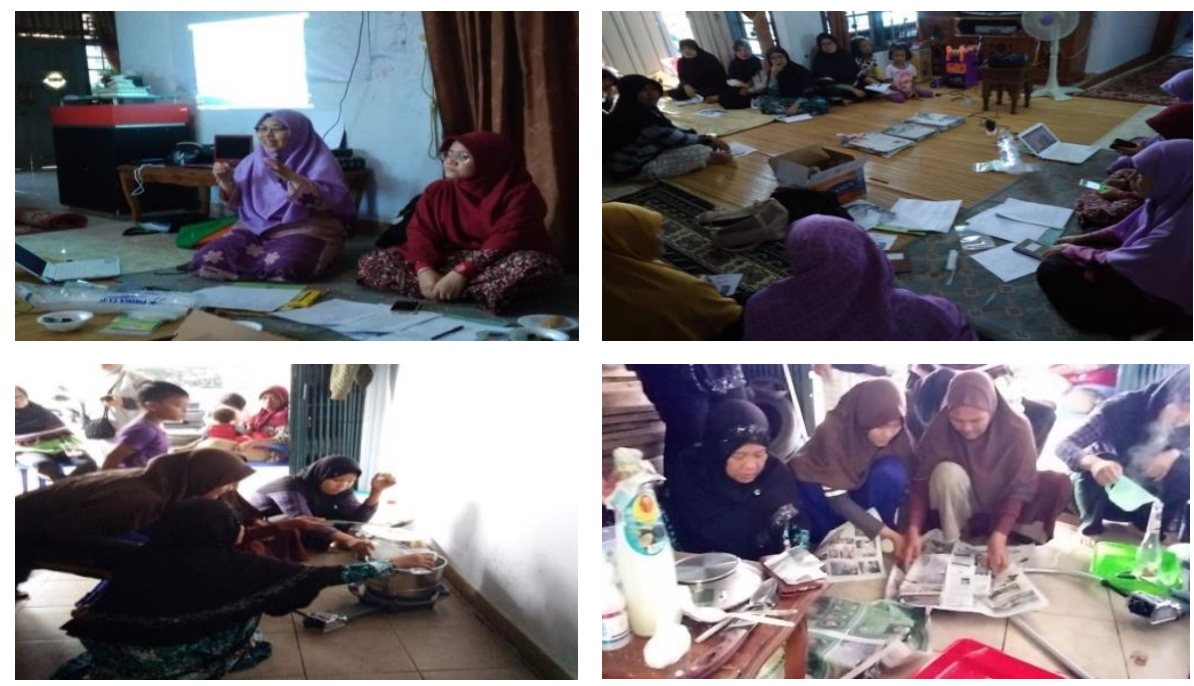

Gambar 2. Pelatihan pembuatan nata de coco

\section{Pemanenan dan Pengolahan Nata De Coco Menjadi Produk Minuman}

Pemanenan nata de coco dilakukan setelah 8 hari fermentasi. Nata de coco layak dipanen jika air kelapa telah berubah bentuk menjadi lembaran nata yang padat. Lembaran nata ini selanjutnya dicuci dengan air bersih dan tidak lupa membuang lapisan tipis di bagian bawahnya. Pencucian dilakukan hendaknya dengan air yang mengalir. Nata yang sudah bersih kemudian dipotong membentuk dadu berukuran $1 \mathrm{~cm} \times 1 \mathrm{~cm}$. Selanjutnya dicuci kembali dan direbus hingga tidak terasa asam. Nata de coco yang telah bebas dari asam, direbus dengan menambahkan gula pasir. Nata ini sudah siap diolah menjadi minuman atau pangan lainnya.

Pada pelatihan ini, peserta membuat minuman nata de coco dengan penambahan flavor, diantaranya flavor leci. Peserta merasa sangat puas dengan pelatihan ini setelah berhasil membuat minuman dari nata de coco yang diproduksi sendiri.
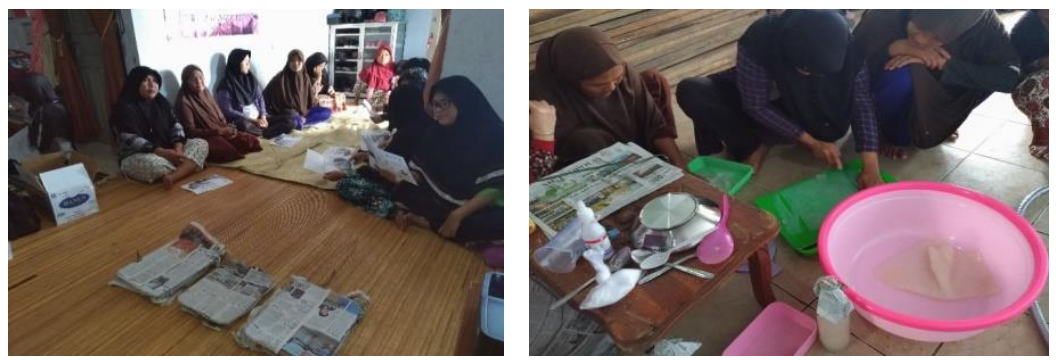

Gambar 3. Pemanenan nata de coco \& pembuatan minuman nata de coco

\section{Pengemasan Dan Pelabelan Produk Nata De Coco}

Nata de coco yang dihasilkan diharapkan tidak hanya untukkonsumsi sendiri tetapi juga dapat dipasarkan sehingga dapat menambah penghasilan ibu-ibu peserta. Nata de coco yang akan dipasarkan tentunya perlu di kemas dengan baik. Fungsi kemasan selain sebagai wadah produk yang menjaga dan melindungi dari berbagai kerusakan, kemasan juga berfungsi sebagai pemberi informasi dan daya tarik konsumen untuk memilih produk yang dipasarkan. Syarif (2017) menjelaskan bahwa ada 6 fungsi utama kemasan yang seharusnya dipenuhi oleh suatu bahan pengemas, yaitu: 
a. Menjaga produk bahan pangan atau hasil pertanian agar tetap bersih dan terlindung dari kotoran dan kontaminasi.

b. Melindungi makanan dari kerusakan fisik, perubahan kadar air dan penyinaran.

c. Mempunyai kemudahan dalam membuka atau menutup, dan juga memudahkan dalam tahap-tahap penanganan, pengangkutan dan distribusi.

d. Mempunyai fungsi yang baik efisien dan ekonomis, aman untuk lingkungan.

e. Mempunyai ukuran, bentuk dan bobot yang sesuai dengan norma atau standar yang ada, mudah dibuang dan mudah dibentuk atau dicetak.

f. Menampilkan identifikasi, informasi, daya tarik dan penampilan yang jelas sehingga dapat membantu promosi atau penjualan.

Pengemasan nata de coco dapat dilakukan dalam berbagai jenis kemasan. Pada kegiatan ini, nata de coco dikemas dalam dua jenis kemasan yaitu kemasan gelas dan kemasan pouch. Pengemasan nata de coco dalam gelas dilakukan dengan bantuan cup sealer, sedangkan pengemasan dalam pouch dibantu oleh plastic sealer untuk merekatkan penutupnya.

Kemasan yang baik harus mampu memberikan informasi mengenai produk yang dikemas. Oleh karenanya, kemasan harus dilengkapi dengan label. Rahmawati (2013) menyebutkan bahwa label pada kemasan pangan harus dapat memberikan informasi produk yang sebenarnya. Diharapkan foto atau gambar tidak menimbulkan kebingungan bagi konsumen serta label dapat menjadi penciri produsen (dapat berupa merek dalam bentuk tulisan maupun gambar). Beberapa informasi yang dapat disampaikan melalui kemasan antara lain merek produk, nama produk, nama produsen, alamat produksi dan telephon yang bisa dihubungi, tanggal produksi \& kadaluarsa, kandungan gizi, komposisi, berat bersih, metode penyimpanan \& penyajian, saran penyajian, sertifikasi, hal-hal istimewa yang menjadikan produk menjadi unggul (contoh: tanpa MSG, tanpa pengawet, tanpa formalin, dll).

Pada kegiatan ini, label menggunakan stiker yang telah dicetak sebelumnya. Stiker yang digunakan adalah stiker transparan dan nontransparan. Stiker transparan dipakai pada kemasan pouch. Tujuannya agar nata de coco yang ada di dalam kemasan dapat terlihat.
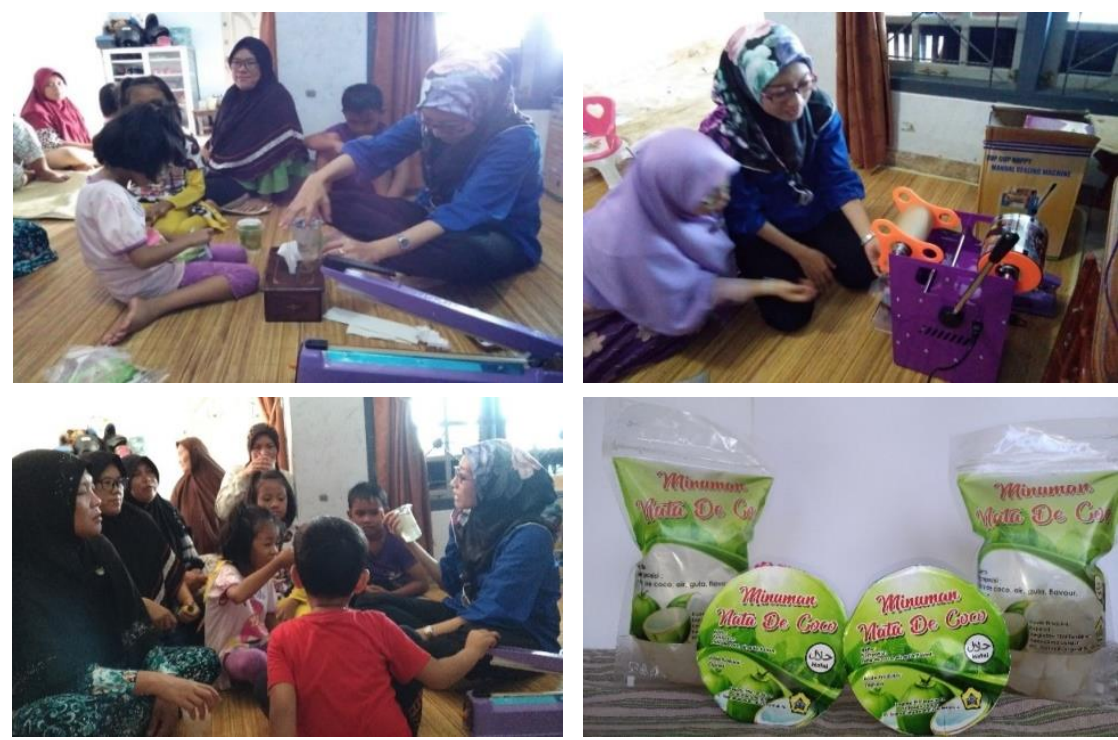

Gambar 4. Pengemasan nata de coco 


\section{Perhitungan Harga Jual Produk}

Harga menjadi salah satu pertimbangan penting bagi konsumen dalam membeli produk. Penetapan harga jual produk memiliki peran penting dalam proses penjualan. Menurut Gayatri (2013), harga jual suatu produk perlu ditetapkan yang dimaksudkan untuk pencapaian laba. Harga jual suatu produk mempengaruhi posisi persaingan pasar yang selanjutnya akan mempengaruhi volume produksi. Dapat dikatakan bahwa harga jual mepengaruhi besarnya pendapatan dan laba bersih perusahaan. Kesalahan dalam menentukan harga jual memungkinkan kita berhadapan dengan beberapa hal antara lain adalah produk tidak laku karena terlalu mahal, atau usaha merugi karena harga terlalu murah sehingga tidak mampu menutupi biaya produksi. Beberapa faktor yang mempengaruhi penentuan harga jual suatu produk antara lain :

a. Konsumen; harga jual harus disesuaikan dengan daya beli konsumen yang menjadi target market.

b. Biaya; harga jual diharapkan mampu menutupi semua biaya yang telah dikeluarkan untuk proses produksi.

c. Kompetitor; harga pasaran untuk produk sejenis yang ditawarkan kompetitor lain.

d. Keuntungan usaha; harga jual dikatakan pantas apabila dapat memberikan laba sesuai dengan yang diharapkan.

Analisa usaha produk nata de coco ini dilakukan dengan beberapa asumsi, antara lain :

a. Satu kali produksi menggunakan 10 liter air kelapa

b. Satu kali produksi menghasilkan $4,5 \mathrm{~kg}$ nata de coco

c. Kemasan yang digunakan adalah kemasan gelas berisi \pm 100 gram/kemasan, sehingga dihasilkan 45 kemasan gelas untuk satu kali produksi.

Perhitungan analisa rencana usaha pada pembuatan nata de coco untuk satu kali produksi disajikan sebagai berikut :

A. Biaya pembelian bahan

Tabel 1. Rincian biaya pembelian bahan

\begin{tabular}{cllr}
\hline No. & & Keterangan & Harga (Rp) \\
\hline 1. & Air kelapa & & 10.000 \\
2. & Gula pasir & 20.000 \\
3. & Asam cuka & 5.000 \\
4. & Urea & 175 \\
5. & Essence & 1.250 \\
6. & Kemasan \& label & 20.000 \\
\hline & Total & $\mathbf{5 6 . 4 2 5}$ \\
\hline
\end{tabular}

B. Biaya operasi

Tabel 3. Riancian biaya operasi produksi

\begin{tabular}{|c|c|c|}
\hline No. & Keterangan & Harga (Rp) \\
\hline 1. & Biaya listrik & 5.000 \\
\hline 2. & Biaya gas & 10.000 \\
\hline 3. & Biaya air & 5.000 \\
\hline 4. & Biaya tenaga kerja & 10.000 \\
\hline & Total & 30.000 \\
\hline
\end{tabular}


C. Hasil produksi :

Pemakaian air kelapa sebanyak 10 liter menghasilkan nata de coco $\pm 4,5 \mathrm{~kg}$. Pengemasan menggunakan kemasan gelas yang diisi sebanyak \pm 100 gram/kemasan. Sehingga dihasilkan 45 gelas minuman nata de coco.

D. Keuntungan :

Total pengeluaran $=\operatorname{Rp} 56.425+\operatorname{Rp} 30.000=\mathbf{R p ~ 8 6 . 4 2 5 , -}$

Harga pokok per kemasan $=\operatorname{Rp} 86.425: 45$ gelas $=$ Rp 1.920,-

Total penjualan $=45$ gelas $x$ Rp $3.000=\mathbf{R p ~ 1 3 5 . 0 0 0 , -}$

Keuntungan $=\operatorname{Rp} 135.000-\operatorname{Rp} 86.425=$ Rp 48.575,-

\section{KESIMPULAN DAN SARAN}

\section{Kesimpulan}

Kegiatan pengabdian mengenai pembuatan nata de coco dilakukan dengan beberapa tahapan kegiatan dan berlangsung dengan lancar. Kegiatan ini mendapat respon yang positif dari peserta. Peserta kegiatan mengikuti semua tahapan kegiatan dengan sangat antusias. Pembuatan nata de coco yang tidak terlalu rumit, menjadikan hal ini sebagai sesuatu yang bermanfaat untuk dijadikan sebagai salah satu alternatif sumber pendapatan.

\section{Saran}

Saran dari kegiatan ini adalah agar dapat dilanjutkan dengan melakukan pendampingan kepada peserta agar dapat terbentuk kelompok usaha yang berkelanjutan. Pelatihan-pelatihan untuk pembuatan olahan nata de coco lainnya masih sangat dibutuhkan. Selain itu, upaya pemasaran produk dan pemahaman mengenai keamanan pangan juga perlu terus dibantu.

\section{DAFTAR PUSTAKA}

Pambayun, R., 2002, Teknologi Penggolahan Nata de Coco, Yogyakarta: Kanisius. Rahmawati, F., 2013, Pengemasan dan Pelabelan. Modul Pelatihan Kewirausahaan Bagi Kelompok UPPKS BPPM DIY, Disampaikan pada tanggal 9-11 September 2013, staffnew.uny.ac.id/upload/132296048/pengab dian/pengemasan-dan-pelabelan.pdf, diakses tanggal 22 Maret 2018.

Gayatri, W., 2013, Penentuan Harga Jual Produk Dengan Metode Cost Plus Pricing Pada Pt.Pertani (Persero) Cabang Sulawesi Utara, Jurnal EMBA Vol.1 No.4: 1817-1823.

Syarief, R., 2017, Pengemasan dan Perlindungan Mutu Bahan Pangan, Model Pengemasan Pangan, repository.ut.ac.id/4605/1/PANG4227-M1.pdf, diakses tanggal 22 Maret 2018. 
Dharma Raflesia Unib Tahun XVII, Nomor 1 Juni 201964 